\title{
Myxidium biliare sp. n. (Myxozoa) from gall bladder of Galaxias maculatus (Osmeriformes: Galaxiidae) in Patagonia (Argentina)
}

\author{
Gustavo P. Viozzi and Verónica R. Flores
}

Laboratorio de Parasitología, Centro Regional Universitario Bariloche, Universidad Nacional del Comahue, Quintral 1250, (8400) San Carlos de Bariloche, Río Negro, Argentina

Key words: Myxidium biliare, Myxosporea, Galaxias maculatus, fish, Patagonia, Argentina

\begin{abstract}
Myxidium biliare sp. n., a new myxosporean species parasitizing the gall bladder of Galaxias maculatus (Jenyns), in Patagonia, is described. Its coelozoic plasmodia were floating free in the bile. Spores are fusiform $13.7 \pm 0.9 \mu \mathrm{m}$ long and $6.9 \pm$ $0.6 \mu \mathrm{m}$ wide, with rounded ends in frontal view and slightly pointed ends in sutural view; shell with ridges and sinuous sutural line. Both maximum prevalence and maximum percentage of immature plasmodia occurred in summer. In winter the prevalence and the percentage of immature plasmodia fell to their lowest values. Prevalence was independent of host sex but increased with host length. Prevalence in 15 Patagonian Andean lakes (situated from $39^{\circ} 25^{\prime} \mathrm{S}$ to $41^{\circ} 30^{\prime} \mathrm{S}$ ) ranged between $4.2 \%$ and $70 \%$.
\end{abstract}

Four species of Myxobolus Bütschli, 1882 have been recorded from Galaxias maculatus (Jenyns) throughout its distribution range. In New Zealand, Hine (1976) described Myxobolus iucundus Hine, 1976 parasitizing muscles. In Tierra del Fuego, Szidat (1953) described M. magellanicus Szidat, 1953 in gills and M. galaxii Szidat, 1953 in muscles and organs of the abdominal cavity. In Falkland Islands Kalavati et al. (2000) described M. bartoni Kalavati, Brickle et MacKenzie, 2000 in the trunk musculature. Viozzi (1996) recorded the presence of spores of an unnamed species of Myxidium Bütschli, 1882 in the gall bladder of $G$. maculatus in a Patagonian Andean lake. The aim of this study is to describe this new species of Myxidium, to provide information about its distribution range in north-western Patagonia and to describe the variation in its prevalence in relation to season and host sex and length from a Patagonian oligotrophic lake.

\section{MATERIALS AND METHODS}

The principal sampling locality was Lake Moreno $\left(41^{\circ} 04^{\prime} \mathrm{S}, 71^{\circ} 33^{\prime} \mathrm{W}\right)$, an oligotrophic lake situated $764 \mathrm{~m}$ above sea level. It has a surface area of $5.4 \mathrm{~km}^{2}$ with a maximum depth of $112 \mathrm{~m}$. Its temperature varies throughout the year from $6^{\circ} \mathrm{C}$ to $20^{\circ} \mathrm{C}$. The other 15 surveyed lakes are situated between $39^{\circ} 25^{\prime} \mathrm{S}, 71^{\circ} 20^{\prime} \mathrm{W}$ and $41^{\circ} 30^{\prime} \mathrm{S}, 71^{\circ} 40^{\prime} \mathrm{W}$. They belong to the Araucanian Region and are also oligotrophic.

Galaxias maculatus is a widely distributed freshwater fish, known from Australia, Tasmania, New Zealand, South America and Falkland Islands. Both diadromous and landlocked populations can be found in South America.

Samples of G. maculatus were collected with baited traps. In Lake Moreno, they were captured monthly from November 1998 to November 1999; water temperature was also recorded monthly. One sample only in spring, summer or autumn was collected from the other lakes. Fish were transported to the laboratory and kept at a controlled temperature $\left(6^{\circ} \mathrm{C}\right)$ until killed and examined between 24 and 72 hours after capture. Sex and total length of fish were recorded, the gall bladder dissected to obtain the trophozoites and the presence of mature spores recorded. In order to prepare and describe trophozoites and spores, Lom and Arthur's (1989) guideline was followed. Morphometric measurements were based on 90 fresh spores obtained randomly from different trophozoites. Spores were studied with a compound microscope and drawn with the aid of a camera lucida. Some gall bladders were fixed in $10 \%$ buffered formalin, dehydrated in a graded ethanol series, cleared in xylene and embedded in paraffin. Histological sections ( $7 \mu \mathrm{m}$ thick) were stained with a Mallory's trichrome. Measurements are given in micrometres.

Monthly sample data were grouped by season according to water temperature as follows: winter samples under $10^{\circ} \mathrm{C}$, spring and autumn samples between 10 and $15^{\circ} \mathrm{C}$ and summer samples over $15^{\circ} \mathrm{C}$. Seven hundred and seven G. maculatus (mean length $49.9 \pm 8.1 \mathrm{~mm}$; range $23.3-85.5 \mathrm{~mm}$ ) from Lake Moreno were examined. The sex of 599 specimens was determined, of which 327 were females and 272 males. To study the annual infection cycle, the presence of mature spores in plasmodia was recorded. The relationship between prevalence and season was tested by an $\mathrm{R} \times \mathrm{C}$ test of independence using the T-test $(P<0.05)$ (Conover 1980). The covariation of prevalence and host length was analysed using the Spearman rank correlation test $(P<0.05)$. A Chi-square test was carried out in order to examine the relation between prevalence and host sex $(P<0.05)($ Conover 1980).

\section{RESULTS}

Myxidium biliare sp. $\mathrm{n}$.

Figs. 1-3

\section{Description}

Coelozoic plasmodia numbering 1-6 were seen through the gall bladder wall, floating free in bile. They were not found in any other organs. Gross pathological 


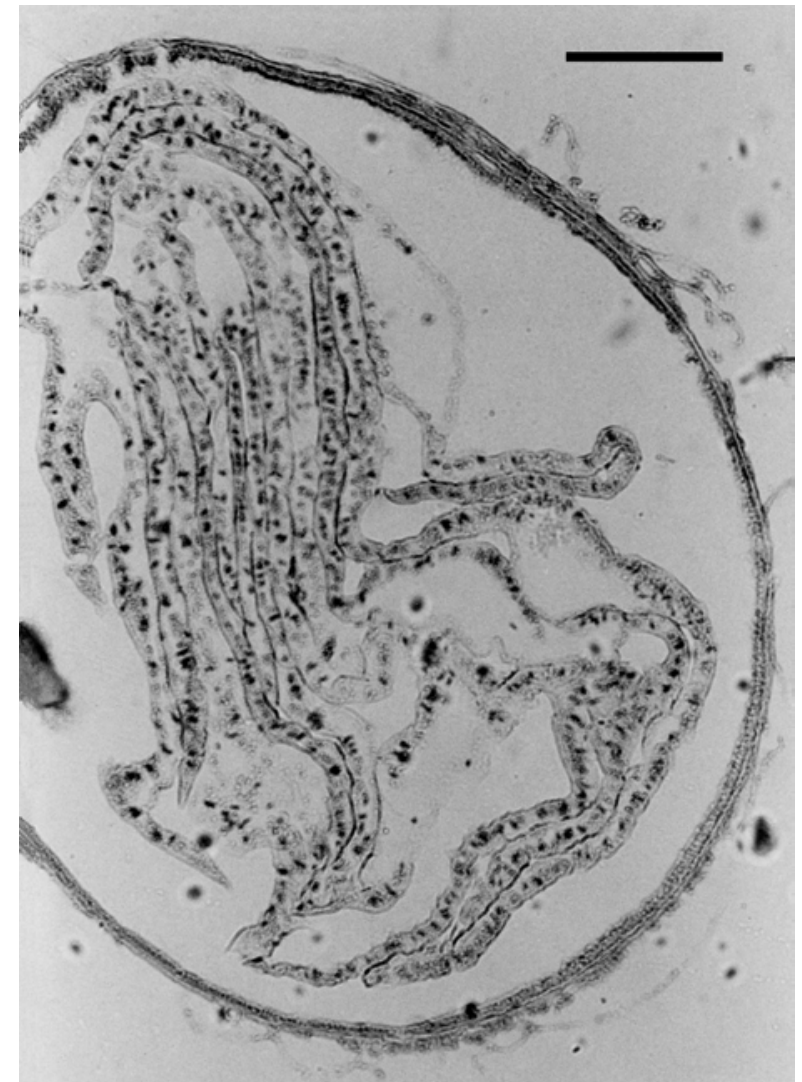

Fig. 1. Histological section of gall bladder with a folded plasmodium of Myxidium biliare $\mathrm{sp}$. $\mathrm{n}$. Scale bar $=150 \mu \mathrm{m}$.

signs in parasitized gall bladders were not observed. Plasmodia were 2,048 \pm 555 (range 1,420-3,690; $\mathrm{n}=$ 20) long, flat, folded; they occupied most of the volume of the gall bladder (Fig. 1). They contained numerous pansporoblasts and spores. Sporogenesis asynchronous, pansporoblast disporoblastic. Ectoplasm narrow.

Mature spores fusiform with rounded ends in frontal view and slightly conical ends in sutural view. Shell with 7-9 ridges on the surface of each valve. Sutural line slightly sinuous. Fresh spores $13.7 \pm 0.9$ (12-15) long, $6.9 \pm 0.6(6-8)$ wide and $6.9 \pm 0.6(6-9)$ thick. Polar capsules at opposite ends of spores, equal in size, $5.7 \pm 0.5$ (5-6) long, pyriform, rounded in proximal zone, with a narrow, slightly curved distal end and openings at tips of spores. In some specimens polar capsules slightly angled to one another. Polar filaments with 5-7 coils. Single sporoplasm located between polar capsules (Figs. 2, 3).

\section{Taxonomic summary}

$\mathrm{T}$ y $\mathrm{p}$ e $\mathrm{h}$ o s t : Galaxias maculatus (Jenyns, 1842) (Osmeriformes, Galaxiidae).

T y p e 1 o c a 1 it y : Lake Moreno ( $\left.41^{\circ} 04^{\prime} \mathrm{S}, 71^{\circ} 33^{\prime} \mathrm{W}\right)$.

Site of infection: Gall bladder.

Overall prevalence in type 1 ocality: $37 \%$ $(260 / 707)$.

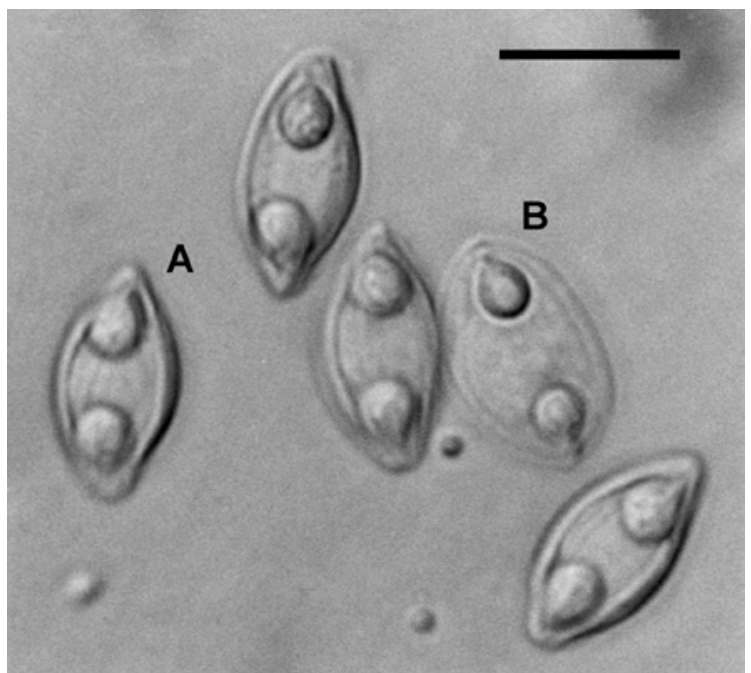

Fig. 2. Spore of Myxidium biliare sp. $\mathrm{n}$. in sutural view (A) and in frontal view (B). Scale bar $=10 \mu \mathrm{m}$.
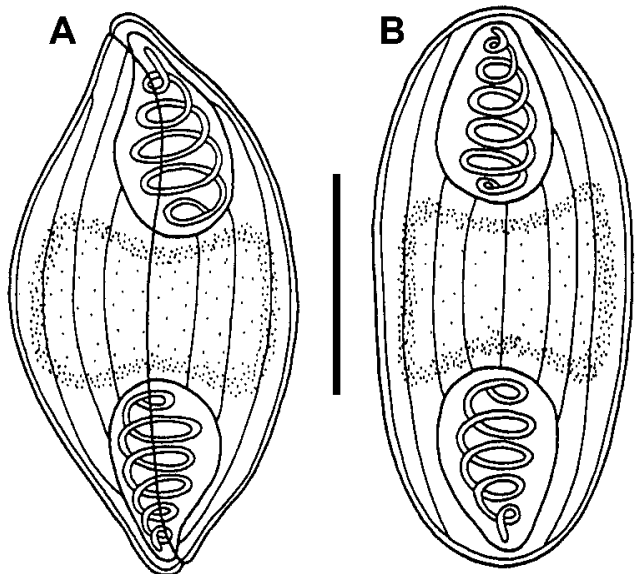

Fig. 3. Line drawing of spore of Myxidium biliare sp. $\mathrm{n}$. in sutural view (A) and in frontal view (B). Scale bar $=5 \mu \mathrm{m}$.

$\mathrm{O}$ th e r 1 o c a $1 \mathrm{it}$ i e s (lake name, coordinates, infected fish/examined fish) : Quillén, $39^{\circ} 25^{\prime} \mathrm{S}, 71^{\circ} 20^{\prime} \mathrm{W},(4 / 10)$; Lácar, $40^{\circ} 10^{\prime} \mathrm{S}, 71^{\circ} 30^{\prime} \mathrm{W}$, (2/31); Villarino, 40²8'S, $71^{\circ} 35^{\prime} \mathrm{W},(9 / 20)$; Falkner, $40^{\circ} 28^{\prime} \mathrm{S}, 7^{\circ} 30^{\prime} \mathrm{W},(14 / 20)$; Filo Hua Hum, $40^{\circ} 30^{\prime} \mathrm{S}, 71^{\circ} 20^{\prime} \mathrm{W},(8 / 20)$; Espejo, 40 $41^{\prime} \mathrm{S}$, $71^{\circ} 42^{\prime} \mathrm{W},(1 / 24)$; Traful, $40^{\circ} 37^{\prime} \mathrm{S}, 7^{\circ} 35^{\prime} \mathrm{W},(14 / 24)$; Correntoso, $40^{\circ} 44^{\prime} \mathrm{S}, \quad 71^{\circ} 39^{\prime} \mathrm{W}, \quad(3 / 28)$; Piré, $40^{\circ} 44^{\prime} \mathrm{S}$,

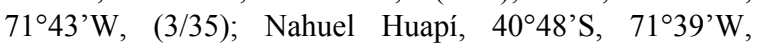
(4/25); El Trébol, $41^{\circ} 05^{\prime} \mathrm{S}, 7^{\circ} 30^{\prime} \mathrm{W}$, (1/4); Gutiérrez, $41^{\circ} 11^{\prime} \mathrm{S}, 71^{\circ} 25^{\prime} \mathrm{W},(2 / 40)$; Mascardi, $41^{\circ} 17^{\prime} \mathrm{S}, 71^{\circ} 34^{\prime} \mathrm{W}$, (13/81); Roca, $41^{\circ} 21^{\prime} \mathrm{S}, \quad 71^{\circ} 45^{\prime} \mathrm{W}, \quad(8 / 25)$; Steffen, $41^{\circ} 30^{\prime} \mathrm{S}, 71^{\circ} 40^{\prime} \mathrm{W},(3 / 27)$.

Voucher specimens deposited: Slides with histological sections (No. ZW 1500) and a whole parasitized gall bladder fixed in $10 \%$ buffered formalin (No. ZW 1501), in the Museum of New Zealand, Te Papa 


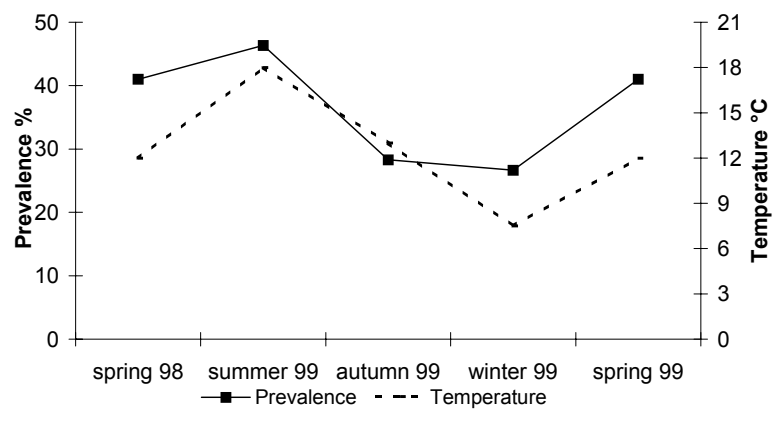

Fig. 4. Seasonal fluctuation of temperature and prevalence of Myxidium biliare sp. n. in Galaxias maculatus from Lake Moreno.

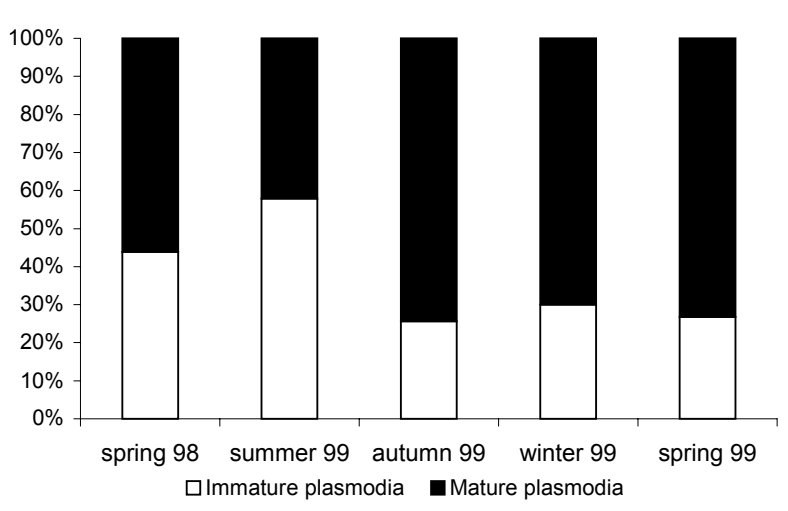

Fig. 5. Percentage of mature/immature plasmodia of Myxidium biliare sp. $\mathrm{n}$. in relation to seasons in Lake Moreno.

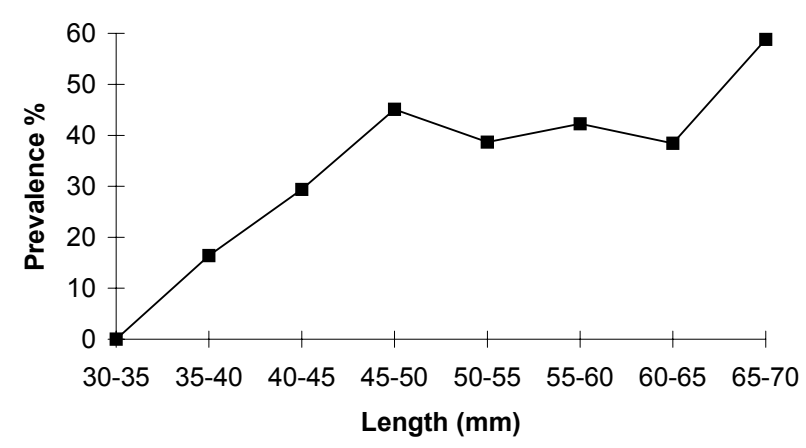

Fig. 6. Prevalence of Myxidium biliare sp. n. in relation to length of Galaxias maculatus in Lake Moreno.

Tongarewa, New Zealand; slides with histological sections (No. 408/1-3) and a whole parasitized gall bladder fixed in $10 \%$ buffered formalin (No. 408/4) in the Helminthological Collection of the Museo Argentino de Ciencias Naturales Bernardino Rivadavia (MACN), Buenos Aires, Argentina; slides with histological sections (No. 151/1-4) in the Colección Parasitológica de la Universidad Nacional del Comahue (Bariloche, Argentina), San Carlos de Bariloche, Argentina; a slide with histological section (No. H-PM-
069 ) and two whole parasitized gall bladders fixed in $10 \%$ buffered formalin (No. H-PM-069m) in the Collection of the Institute of Parasitology, Academy of Sciences of the Czech Republic, České Budějovice.

E t y m o lo g y: The species name refers to its localisation in the gall bladder of the host.

\section{Seasonal occurrence and relation of prevalence to} host's sex and length

The maximum prevalence of $M$. biliare was observed in summer $(46.3 \%)$ and minimum prevalence $(26.7 \%)$ in winter (Fig. 4). There were significant differences in prevalence between seasons $(\mathrm{T}=13.31$; $\mathrm{df}=4 ; P<$ $0.05)$. The highest percentage of sporogenic plasmodia were observed from autumn to spring while the minimum percentage was in summer (Fig. 5).

The prevalence of $M$. biliare was $36.7 \%$ in females and $32.1 \%$ in males and was independent of host sex $\left(X^{2}=0.229 ; \mathrm{df}=1 ; P>0.05\right)$. There was a significant positive correlation between prevalence of $M$. biliare and total length of the host ( $\mathrm{rs}=0.786 ; P=0.021$ ) (Fig. 6).

\section{DISCUSSION}

Lom and Dyková (1992) listed 149 species of Myxidium Bütschli, 1882 in marine and freshwater fishes. The spores of Myxidium spp. are, as a rule, fusiform, straight or slightly crescentic or sigmoid, with more or less pointed ends, smooth or with ridges, with the sutural line bisecting the spore, and with two pyriform polar capsules. The capsular openings are situated in the sutural plane near the end of the spores and usually open in opposite directions. One sporoplasm is located between polar capsules (Lom and Dyková 1992). In comparison, the spores of Zschokkella Auerbach, 1910 are ellipsoidal in sutural view, slightly bent or semicircular in valvular view, with rounded blunt ends, straight, curved or sinuous sutural lines and with almost spherical polar capsules (Lom and Dyková 1992). Canning et al. (1999) pointed out that there is a considerable overlap in the characteristics of these two genera. Although the distinction between Myxidium and Zschokkella is arbitrary and still under discussion (Diamant et al. 1994), our species displays characteris-tics that fit more closely to the morphological features listed for Myxidium by Lom and Dyková (1992).

Pinto (1928) reported three species of Myxidium from the gall bladder of freshwater fishes in Brazil, but the ranges of the spore length and width do not agree with those of $M$. biliare. Moreover, the Brazilian species parasitize characiform and ophidiform fishes.

Myxidium biliare has a wide distribution in Patagonian Andean lakes (39 $\left.25^{\prime} \mathrm{S}-41^{\circ} 30^{\prime} \mathrm{S}\right)$, inhabiting landlocked G. maculatus populations of Atlantic and Pacific watersheds. This is the first species of Myxidium de- 
scribed from galaxiid fishes and from any freshwater fish in Argentina.

Infection by spores of $M$. biliare is independent of host sex. This is the typical situation found in myxosporidiosis, and has also been described for species of the genus Ceratomyxa Thélohan, 1842 in Dicentrarchus labrax (Linnaeus) (Alvarez Pellitero and Sitjà Bobadilla 1993) and for M. magellanicus in G. maculatus (Flores and Viozzi 2001).

Cone (1994) and Molnár (1998) found clear evidence of seasonal cycles of Henneguya doori Guilford, 1963 and H. creplini (Gurley, 1894) parasitizing gills. They found sporogenic plasmodia with fully developed spores only from end of winter to spring. By contrast, immature and mature plasmodia of $M$. biliare were found in all seasons, so this myxosporean does not seem to have a clear seasonal cycle. However, the periods of recruit-ment and spore release exhibit some seasonality, as evidenced by the low prevalence and the higher percentage of mature plasmodia in winter and the high prevalence and the lower percentage of mature plasmodia in summer. From autumn to spring, a higher percentage of plasmodia would result in seasonal spore production and part of the fish population would shed them from the gall bladder through the intestine. Cone (1994) pointed out that marked seasonal fluctuation in the prevalence of myxosporideans appears to be common in those species having cysts on exposed surfaces of the host. Those species which infect internal tissues such as muscles, cartilage or nerves cannot have such cycles. Although the gall bladder is an internal organ, mature spores of $M$. biliare can easily reach water through the intestine, so there can be periods in which mature spores can be released.

Like the prevalence of $H$. creplini in Stizostedion lucioperca (Linnaeus) (Molnár 1998), the prevalence of $M$. biliare in G. maculatus increases with the length of the fish. The larval and young G. maculatus have planktonic habits and live in the limnetic zone, and the older fishes spend more time in the littoral, swimming in schools (Barriga et al. 2002). If the parasite employs an oligochaete worm as intermediate host, like $M$. giardi Cépede, 1906 (Benajiba and Marques 1993), the infection of larval and young fishes would therefore be rare. On the other hand, if the transmission of this species proceeds from fish to fish as in the case of Enteromyxum leei (Diamant, Lom et Dyková, 1994), (Diamant 1997), the chances of becoming infected would increase in the older and longer age class due to the longer time the hosts have been exposed to infectious spores.

Acknowledgements. We thank Clive R. Kennedy for English revision of the manuscript, Ana Kreiter for histological sections and Gernot Vobis for helping with the photomicrographs. Financial support for this study was provided by Universidad Nacional del Comahue (UNC-B 092/99) and FONCYT-PICT (01-00002-00067).

\section{REFERENCES}

ALVAREZ PELLITERO P., SITJÀ BOBADILLA A. 1993 Ceratomyxa spp. (Protozoa: Myxosporea) infection in wild and cultured sea bass, Dicentrarchus labrax from Spanish Mediterranean area. J. Fish Biol. 42: 889-901.

BARRIGA J.P., BATTINI M., MACCHI P., MILANO D., CUSSAC V. 2002: Spatial and temporal distribution of landlocked Galaxias maculatus and Galaxias platei (Pisces: Galaxiidae) in a lake in the South American Andes. N. Z. J. Mar. Freshwater Res. 36: 345-359.

BENAJIBA M.H., MARQUES A. 1993: The alternation of actinomyxidian and myxosporidian sporal forms in the development of Myxidium giardi (parasite of Anguilla anguilla) through oligochaetes. Bull. Eur. Assoc. Fish Pathol. 13: 100-103.

CANNING E., CURRY A., ANDERSON C., OKAMURA B. 1999: Ultrastructure of Myxidium trachinorum sp. nov. from the gallbladder of the lesser weever fish Echiichthys vipera. Parasitol. Res. 85: 910-919.

CONE D.K. 1994: Annual cycle of Henneguya doori (Myxosporea) parasitizing yellow perch (Perca flavescens). J. Parasitol. 80: 900-904.

CONOVER W.J. 1980: Practical Nonparametric Statistics. 2nd Ed. John Wiley \& Sons, New York, 493 pp.

DIAMANT A. 1997: Fish-to-fish transmission of a marine myxosporean. Dis. Aquat. Org. 30: 99-105.
DIAMANT A., LOM J., DYKOVÁ I. 1994: Myxidium leei n. sp., a pathogenic myxosporean of cultured sea bream Sparus aurata. Dis. Aquat. Org. 20: 137-141.

FLORES V., VIOZZI G.P. 2001: Redescription, seasonality and distribution of Myxobolus magellanicus (Myxosporea) in Galaxias maculatus (Osmeriformes, Galaxiidae) from Patagonian Andean lakes (Argentina). Acta Parasitol. 46: 159-163.

HINE P.M. 1976: Myxobolus iucundus n. sp. (Sporozoa, Myxosporidea) parasitic in Galaxias maculatus (Jenyns, 1842). J. R. Soc. N. Z. 2: 157-161.

KALAVATI C., BRICKLE P., MacKENZIE K. 2000: Two new species of myxozoan parasites (Myxosporea, Multivalvulida, Bivalvulida) from fishes of the Falkland Islands. Acta Parasitol. 45: 285-288.

LOM J., ARTHUR R. 1989: A guideline for the preparation of species descriptions in Myxosporea. J. Fish Dis. 12: 151-156.

LOM J., DYKOVÁ I. 1992: Protozoan Parasites of Fishes. Developments in Aquaculture and Fisheries Science, Vol. 26. Elsevier, London, UK, 315 pp.

MOLNÁR K. 1998: Taxonomic problems, seasonality and histopathology of Henneguya creplini (Myxosporea) infection of pikeperch Stizostedion lucioperca in Lake Balaton. Folia Parasitol. 45: 261-269. 
PINTO C. 1928: Myxosporideos e outros protozoarios intestinaes de peixes observados na America do Sul. Arch. Inst. Biol. 1: 101-140.

SZIDAT L. 1953: Einige neue Arten der Familie Myxobolidae Thélohan (Protozoa, Klasse Sporozoa) aus

Received 2 September 2002
Süßwasser-fischen Argentiniens. Gewässer und Abwässer 5: 7-16.

VIOZZI G.P. 1996: Presencia de protozoos parásitos en peces autóctonos de Patagonia Argentina. Bol. Chil. Parasitol. 51: $32-34$.

Accepted 10 January 2003 